\title{
Lepirudin in the management of patients with heparin-induced thrombocytopenia
}

\author{
Sirak Petros \\ Department of Internal Medicine, \\ University of Leipzig, Leipzig, \\ Germany
}

Correspondence: Sirak Petros

University of Leipzig, Department of Internal Medicine, Medical ICU and Clinical Hemostaseology, Liebigstr. 20, D-04I03 Leipzig, Germany

Tel +49 34I 97I 2706

Fax +49 34I 97127I9

Email sirak.petros@uniklinik-leipzig.de

\begin{abstract}
Lepirudin, a recombinant hirudin, is a direct irreversible thrombin inhibitor by binding to both free and clot-bound thrombin. It is approved for treatment of heparin-induced thrombocytopenia (HIT), which is a serious antibody-mediated drug reaction mostly associated with the use of unfractionated heparin. Clinical experience during the last 10 years has proved the efficacy of lepirudin in the management of HIT. The major route of elimination of lepirudin is the kidney, accounting for approximately $90 \%$ of its systemic clearance. The most important adverse reactions are bleeding and the induction of immunologic reactions. The risk of bleeding can be reduced by implementing an optimal monitoring and dose adjustment strategy, particularly in patients undergoing cardiopulmonary bypass surgery and in those with impaired renal function. Development of antihirudin antibodies may enhance the anticoagulant effect of lepirudin. Anaphylactic reactions associated with lepirudin therapy are rare. The lack of an antidote against lepirudin is still a concern, particularly during cardiopulmonary bypass surgery with a heart-lung machine and during artificial renal support. Currently, hemofiltration using high-flux filter systems is the only available and valid means to manage hirudin overdose. Nevertheless, the drug can be safely used if meticulous monitoring strategy is installed.

Keywords: lepirudin, hirudin, heparin-induced thrombocytopenia, direct thrombin inhibitors, bleeding
\end{abstract}

\section{Heparin-induced thrombocytopenia (HIT) Epidemiology of HIT}

Heparin-induced thrombocytopenia (HIT) is a drug-induced antibody-mediated immunological reaction resulting in arterial and/or venous thrombus formation. It can have serious and life-threatening consequences if it is not identified immediately and managed accordingly.

HIT is significantly more common in patients treated with unfractionated heparin (UFH) than in those treated with low-molecular-weight heparins (LMWH) (Warkentin et al 1995; Martel et al 2005) (Table 1).

The frequency of HIT ranges between $0.2 \%$ and $3.0 \%$, depending on the study population, being more common in surgical than in medical patients (Warkentin et al 1995; Girolami et al 2003; Prandoni et al 2005; Smythe et al 2007). With an incidence rate of $0.3 \%-0.5 \%$, HIT is relatively uncommon in the critical care setting (Selleng et al 2007). The frequency of HIT in medical patients on thrombosis prophylaxis with UFH and LMWH is also considerably low, $0.51 \%$ and $0.084 \%$, respectively (Creekmore et al 2006). HIT seems to be more common in acute hemodialysis. In a study on 154 consecutive patients newly treated with hemodialysis, HIT was suspected in $6(3.9 \%)$ and the clinical diagnosis was confirmed in all but one patient (Yamamoto et al 1996). In contrast, in a UK national survey among patients on long-term hemodialysis, the incidence rate of HIT was only $0.32 \%$ (Hutchison and Dasgupta 2007). Although HIT is clearly less frequent in medical than in surgical patients, it is nevertheless associated 
Table I Meta-analysis of the risk of heparin-induced thrombocytopenia (HIT) during thrombosis prophylaxis with low-molecularweight heparin (LMWH) versus unfractionated heparin (UFH) (after Martel et al 2005)

\begin{tabular}{lll}
\hline & HIT & Thrombocytopenia \\
\hline LMWH & $\mathrm{I} / \mathrm{I} 255(0.1 \%)$ & $\mathrm{I} 52 / 3758(4.0 \%)$ \\
UFH & $3 \mathrm{I} / \mathrm{I} 223(2.5 \%)$ & $238 / 3529(6.7 \%)$ \\
Odds ratio & $0.1(0.03-0.33)$ & $0.47(0.22-1.02)$ \\
\hline
\end{tabular}

with a similarly high rate of thromboembolic complications and high treatment costs (Girolami et al 2003; Creekmore et al 2006).

The increasing use of LMWH in thrombosis prophylaxis and treatment has contributed to the reduction in the incidence of HIT. However, despite the introduction of newer anticoagulants in the clinical routine, UFH still remains the anticoagulant of choice in certain medical conditions, particularly during cardiovascular surgery involving cardiopulmonary bypass (CPB) and in a sizable proportion of critically ill patients, thus maintaining the specter of HIT.

\section{Pathogenesis of HIT}

HIT typically occurs 5-10 days after starting on heparin treatment (Warkentin et al 1995). Exposure to heparin molecules leads to expression of antibodies of the immunoglobulin $\mathrm{G}$ (IgG) class that bind to the platelet factor 4-heparin complex. This complex interacts with endothelial cells and platelets, resulting in activation of the coagulation cascade and formation of thrombi (Warkentin 2004; Girolami and Girolami 2006; Greinacher 2006). Thromboembolic complications can affect both the arterial and venous system.

\section{Diagnosis of HIT}

The diagnosis of HIT is primarily based on the course of reduction in platelet count and/or the development of thromboembolic event during treatment with heparin (Warkentin and Heddle 2003). One must be aware of the possibility of this syndrome in any patient receiving either UFH or LMWH, including heparin flush for vascular access devices and extracorporeal systems.

Meticulous history taking and scrutiny of the course of reduction in platelet count are important in the diagnosis of HIT. Before considering every thrombocytopenia as HIT, one should carefully consider other potential causes of thrombocytopenia depending on the clinical condition of the patient. Particularly sepsis, other drug-induced thrombocytopenias and pseudothrombocytopenia should be considered. Nevertheless, HIT should always be suspected and appropriate management immediately implemented unless it is conclusive that other causes of thrombocytopenia are most likely.

Suspecting HIT in critically ill patients presenting with thrombocytopenia while receiving UFH or LMWH may be difficult. Firstly, the rate of thrombocytopenia in this patient group is as high as 30\%-50\% (Strauss et al 2002; Crowther et al 2005). Secondly, critically ill patients often present with an overlap of clinical syndromes (eg, disseminated intravascular coagulation, bone marrow suppression, liver failure, drug toxicity). This complexity may pose a serious diagnostic dilemma regarding HIT. In any case, treatment with heparin must be stopped and nonheparin anticoagulation immediately started until HIT can be ruled out with certainty.

Laboratory diagnosis of HIT is based on the identification of platelet factor 4 antibodies and functional platelet agglutination tests. The identification of HIT antibodies alone without any considerable reduction in platelet count or thrombocytopenia or thrombosis should not be considered as HIT (Warkentin and Heddle 2003; Juhl et al 2006; Greinacher et al 2007). Most of the asymptomatic patients with HIT antibodies do not develop HIT and thus do not need any specific treatment. The sensitivity and specificity of functional tests may be variable, and this may be influenced by the laboratory expertise. In general, a negative laboratory finding does not necessarily rule out HIT (Warkentin and Heddle 2003). A conclusive diagnosis of HIT may thus be illusive in a small number of patients.

\section{Management of HIT}

The first step in the management of HIT is to immediately stop any solution containing heparin and start with a nonheparin anticoagulant. Stopping exposure to heparin alone is not enough in the management of HIT (Wallis et al 1999). Thrombin generation and clot formation as a result of the hemostatic activation due to HIT antibodies continue for several days or weeks even if heparin is stopped (Greinacher et al 1999a; Greinacher et al 1999b; Becker 2000). Therefore, nonheparin anticoagulants that do not cross-react with HIT antibodies should be administered in order to inhibit thrombin or thrombin generation.

Drugs used to treat HIT act by either inhibiting coagulation factor Xa or thrombin. Currently, danaparoid, lepirudin, and argatroban are approved for treatment of HIT. Danaparoid is a glycosaminoglycuronan isolated from porcine intestinal mucosa with an anti-Xa : anti-IIa activity ratio greater than 22 . Its predominant effect is thus neutralizing factor Xa, thereby inhibiting the formation of thrombin. Lepirudin is a recombinant hirudin (r-hirudin) that irreversibly binds to both the 
substrate binding and catalytic sites of thrombin. Bivalirudin, another r-hirudin but with a reversible direct thrombin inhibition, is approved by the Food and Drug Administration (FDA) for use in patients with, or at risk of, HIT undergoing percutaneous coronary intervention. Argatroban is a synthetic direct thrombin inhibitor derived from L-arginine, and it reversibly binds to the active site of thrombin. This review focuses on lepirudin, which is one of the oldest nonheparin anticoagulants used in the management of HIT.

\section{Lepirudin}

\section{Historical background}

Hirudin is a naturally occurring anticoagulant produced by the salivary glands of the medicinal leech Hirudo medicinalis. For several centuries, the leech had been used for medicinal purposes, particularly for bloodletting. Historical data from Persia and India show that the leech was used for such purposes as early as about $100 \mathrm{BC}$.

In his in vitro studies, Haycraft could demonstrate for the first time in 1884 the presence of a substance with anticoagulant properties in the leech extract (Haycraft 1884). The first parenteral anticoagulant treatment with a commercial hirudin was reported in 1909 (Engelmann and Stade 1909). However, inadequate supplies have made it practically impossible for the drug to be used in clinical medicine. The introduction of heparin that could be produced in large quantities changed the focus of research, and hirudin was almost ignored for decades. However, the advent of genetic engineering has made large production of the compound possible, one of the products of this recombinant approach being lepirudin.

The approval of lepirudin for treatment of patients with HIT was based on two prospective studies, the HeparinAssociated Thrombocytopenia (HAT)-1 and HAT-2 trials, which compared its efficacy with a historical cohort (Greinacher et al 1999a, b). A recent investigation, the HAT-3 trial, further underlined the efficacy of lepirudin in the management of HIT (Lubenow et al 2005).

\section{Biochemistry}

Hirudin comprises structurally similar single-chain polypeptides of 65 or 66 amino acids with a compact aminoterminal core containing 3 disulphide bonds and an extended carboxy terminal with a sulphated tyrosine residue (Dodt et al 1984).

Lepirudin ([Leu1, Thr2]-63-desulfatohirudin) has a molecular weight of $6979 \mathrm{Da}$. It is derived from transfected yeast cells using recombinant technology. In contrast to the natural compound, it is homogenous, comprising 65 amino acids, lacks a sulphated tyrosine residue at position 63 (thus termed desulfatohirudin), and contains leucine instead of isoleucine residue at position 1. Lepirudin has a specific activity of approximately 16,000 antithrombin units/mg (Bayer Product Monograph 2007).

\section{Pharmacology of lepirudin}

Mechanism of action

Lepirudin is a direct and irreversible inhibitor of thrombin, which is a key serine protease in the hemostatic system. Thrombin is generated via activation of its zymogen, prothrombin, by the prothrombinase complex (factor $\mathrm{Xa}$ /factor $\mathrm{Va}$ ). The amount and the velocity of thrombin generation are decisive in the development of a stable clot (Hemker et al 2006).

Lepirudin forms a stable noncovalent stoichometric 1:1 complex with thrombin, thereby inhibiting its procoagulant effects. It binds both to the substrate binding and catalytic sites of thrombin. In contrast to heparin, lepirudin is a direct thrombin inhibitor and it inhibits not only free but also clotbound thrombin (Weitz et al 1990).

The effect of lepirudin on thrombin is well described using the thrombin generation assay. Under physiological conditions, a very small amount of thrombin is generated in the initiation phase of the coagulation process, which is then followed by the amplification and propagation phases, culminating in the formation of a large amount of thrombin (Hoffman and Monroe 2001; Roberts et al 2006). Lepirudin prolongs the lag phase during thrombin generation. In therapeutic doses of lepirudin, the amount of generated thrombin (area under the thrombin generation curve) may be normal (Figure 1). However, with increasing doses of lepirudin, thrombin generation can also be reduced (Petros et al 2006).

By inhibiting the thrombin-thrombomodulin-induced protein $\mathrm{C}$ activation, hirudins might theoretically have a procoagulant effect. However, there is no evidence for this assumption.

\section{Absorption and distribution}

Lepirudin is rapidly distributed throughout the extracellular space after intravenous (iv) administration. Its volume of distribution ranges between 12.2 and 32.1 L (Bayer Product Monograph 2007), so that the drug is confined to the extracellular compartment (Markwardt et al 1984; Meyer et al 1990; Vanholder et al 1997). Lepirudin does not cross the bloodbrain barrier (Markwardt et al 1988) and it is not detected in breast milk (Lindhoff-Last et al 2000b). 


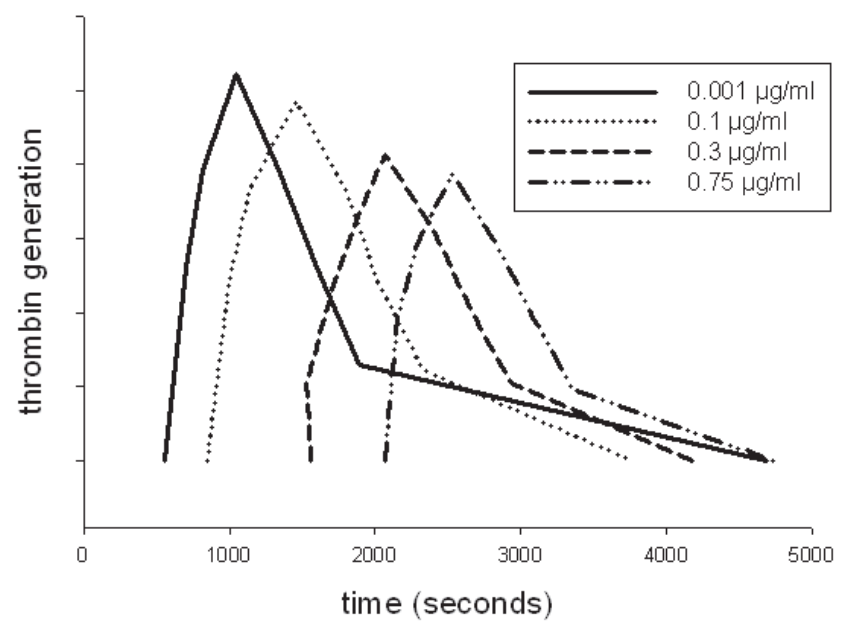

Figure I Effect of lepirudin on thrombin generation. The lag time increases and the area under the thrombin generation curve becomes smaller with increasing dose of lepirudin. The thrombin generation assay was conducted in vitro after spiking platelet-rich plasma from healthy donors with lepirudin. Platelet count was adjusted at $200 \times 10^{9} / \mathrm{mL}$

The pharmacokinetic properties of lepirudin following an iv administration are well described by a two-compartment model (Markwardt et al 1984; Nowak et al 1988; Bayer Product Monograph 2007). The initial plasma half-life of the drug is about 10 minutes, after which it is distributed in the extracellular space. Its terminal half-life in young healthy volunteers is about 1.3 hours. The bioavailability of the drug is also almost $100 \%$ with subcutaneous (sc) administration, with peak plasma drug concentration achieved in 3-4 hours (Verstraete et al 1993; Schiele et al 1994).

Maximum activated partial thromboplastin time (aPTT) is reached about 10 min after an iv bolus, 3-6 hours after a 6-hour continuous iv infusion, and 2-3 hours after sc administration (Greinacher 2004).
The pharmacokinetic profile of lepirudin remains unchanged during repeated administrations, thus drug accumulation is unlikely in healthy state (Nowak et al 1988).

\section{Metabolism and elimination of lepirudin}

The primary elimination route of lepirudin is renal, accounting for approximately $90 \%$ of its systemic clearance (Markwardt et al 1991). It is partially hydrolyzed into amino acids in the kidney. About $35 \%$ of lepirudin is excreted in the urine unchanged (Meyer et al 1990; Nowak et al 1992). The systemic clearance of lepirudin is proportional to the glomerular filtration rate (Bucha et al 1999b). Therefore, the half-life of the drug increases with deterioration of renal function (Nowak et al 1992, 1997; Vanholder et al 1997). The systemic clearance of lepirudin in women is about $25 \%$ lower than in men, and it is $20 \%$ lower in elderly patients than in younger patients (Bayer Product Monograph 2007). These facts should be taken into consideration during lepirudin dosage.

\section{Dosing lepirudin}

Renal function must be taken into consideration while deciding on the initial and maintenance dose of lepirudin. Firstly, renal function declines with age. Secondly, elderly patients are the largest group of candidates for cardiovascular and orthopedic surgery. Thirdly, renal function may deteriorate during critical illness. Fourthly, serum creatinine is dependent on muscle mass, which declines with age. Therefore, simply taking serum creatinine for renal function assessment rather than creatinine clearance may result in overdosing lepirudin.

The dosing recommendations of lepirudin for HIT are given in Table 2 .

Table 2 Dosing recommendation for lepirudin use (intravenous administration) for heparin-induced thrombocytopenia (HIT)

\begin{tabular}{lll}
\hline Clinical condition & $\begin{array}{l}\text { Bolus dose }(\mathbf{m g} / \mathbf{k g} \\
\text { body weight) }\end{array}$ & Maintenance dose \\
\hline HIT with thrombosis & 0.40 & $0.15 \mathrm{mg} / \mathrm{kg} / \mathrm{h}$ \\
HIT without thrombosis & none & $0.10 \mathrm{mg} / \mathrm{kg} / \mathrm{h}$ \\
HIT with thrombosis and & 0.20 & $0.10 \mathrm{mg} / \mathrm{kg} / \mathrm{h}$ \\
$\begin{array}{l}\text { concomitant thrombolysis } \\
\text { thrombosis prophylaxis in }\end{array}$ & none & $0.10 \mathrm{mg} / \mathrm{kg} / \mathrm{h}$ \\
$\begin{array}{l}\text { patients with history of HIT } \\
\text { intermittent hemodialysis }\end{array}$ & $0.08-0.10$ predialysis & none \\
$\begin{array}{l}\text { Continuous veno-venous } \\
\text { hemofiltration }\end{array}$ & none & $0.005 \mathrm{mg} / \mathrm{kg} / \mathrm{h}$ \\
cardiac bypass surgery & 0.25 and 0.20 in the priming & adjusted based \\
& fluid of the heart-lung machine & on ECT
\end{tabular}

Except in cardiac surgery, treatment is generally monitored using aPTT, with a target aPTT ratio of I.5-2.5. In cardiac surgery, anticoagulant monitoring is carried out using ecarin clotting time (ECT), which should be $>2.5 \mu \mathrm{g} / \mathrm{mL}$ before and $3.5-4.5 \mu \mathrm{g} / \mathrm{mL}$ during the cardiopulmonary bypass.

Dose regimens are taken from the Heparin-Associated Thrombocytopenia (HAT) trials (Greinacher et al 1999a, b; Lubenow et al 2005). 
Laboratory monitoring of the anticoagulant effect of lepirudin must be conducted 3-4 hours after starting treatment and 3-4 hours after every dose change. Monitoring twice daily seems prudent. If the therapeutic range is not achieved, the dose should be increased by $20 \%$. In case of overdose, lepirudin infusion must be stopped for 2 hours and then restarted at $50 \%$ of the last dose. Frequent laboratory monitoring and corresponding dose adjustments are necessary in patients undergoing CPB procedures.

\section{Monitoring the anticoagulant effect of lepirudin}

Several assays have been evaluated for monitoring treatment with lepirudin, including the global test activated partial thromboplastin time (aPTT), ecarin clotting time (ECT) and enzyme-linked immunosorbent (ELISA) techniques (Nowak 2001; Hafner et al 2002).

Due to its inhibitory effect on thrombin, lepirudin results in prolongation of both aPTT and prothrombin time (PT). The aPTT is generally the current method of choice for monitoring treatment with lepirudin in most situations. However, there are considerable inter-individual variations in aPTT among patients treated with lepirudin. Furthermore, there is no linear correlation between aPTT and lepirudin at plasma concentrations of lepirudin greater than $0.6 \mathrm{mg} / \mathrm{L}$ (Pötzsch et al 1997b; Moser et al 2001; Hafner et al 2002). This may result in overlooking toxic doses and the danger of bleeding.

The ECT defines the prolongation of clotting time caused by thrombin inhibition alone (Nowak and Bucha 1996; Pötzsch et al 1997a, b; Koster et al 2000b). Ecarin is a metalloprotease obtained from the snake venom of Echis carinatus. It cleaves prothrombin, thereby exclusively generating meizothrombin, which is biologically similar to thrombin. However, meizothrombin cleaves fibrinogen much more slowly than thrombin. Thus, when all of the lepirudin in a blood sample is bound to meizothrombin, thrombin is no longer inhibited, which in turn results in clot formation. ECT shows a linear correlation to wide ranges of plasma lepirudin concentrations. Moreover, the inter-individual variation is low and the assay is not affected by heparin or antifibrinolytics (Pötzsch et al 1997b; Nowak 2001; Hafner et al 2002). ECT is more suitable than aPTT to monitor the anticoagulant effect of lepirudin particularly when higher doses are used, such as in CPB surgery.

Despite the merits of ECT measurement, there is no controlled study that proved the superiority of ECT over aPTT in reducing bleeding risk.

\section{Antagonizing the effects of lepirudin}

There is no specific antidote against lepirudin or any of the other hirudin derivatives. This is a major issue in areas where high anticoagulant activity may be required, particularly in cardiovascular surgery with extracorporeal circulation. In an in vitro model, desmopressin was shown to at least partially antagonize the effect of hirudin (Ibbotson et al 1991). Other animal studies have also reported the use of desmopressin in reversing the effect of hirudin (Butler et al 1993; Bove et al 1996). However, human studies are still lacking. There are case reports on the successful use of recombinant activated factor VII in lepirudin-induced bleeding (Hein et al 2005; Oh et al 2006).

Another means of coping with bleeding due to lepirudin can be extracorporeal elimination systems. Some low-flux and all high-flux dialysis membranes are permeable to r-hirudin and may thus help to lower toxic doses of the drug (Bucha et al 1999a). Other authors concluded that modified ultrafiltration may enhance the elimination of r-hirudin, but plasmapheresis seems to provide the most rapid and complete elimination of the drug (Koster et al 2000c). However, such extracorporeal techniques are not always a practical option in emergency situations.

\section{Clinical efficacy of lepirudin in patients with HIT}

The efficacy of lepirudin in the management of patients with HIT has been proven in the prospective HAT trials (Greinacher et al 1999a, b; Lubenow et al 2005). Clinical results of HIT treatment are shown in Table 3. The results of these studies underscore that once HIT is suspected, treatment should never be delayed. Delay between diagnosis of HIT and start of treatment with an alternative anticoagulant accounted for $61 \%$ of the thromboembolic complications observed during the HAT-3 trial. Summarizing the data of all patients included in the HAT trials, lepirudin decreased the

Table 3 Clinical results of treatment of heparin-induced thrombocytopenia (HIT) with lepirudin (after Lubenow et al 2005)

\begin{tabular}{llll}
\hline $\begin{array}{l}\text { Clinical } \\
\text { condition }\end{array}$ & $\begin{array}{l}\text { Before } \\
\text { treatment }\end{array}$ & $\begin{array}{l}\text { During } \\
\text { treatment }\end{array}$ & $\begin{array}{l}\text { After } \\
\text { treatment }\end{array}$ \\
\hline death & 0 & $4.4 \%$ & $10.2 \%$ \\
limb amputation & $1.0 \%$ & $4.9 \%$ & 0 \\
new thromboembolic & $8.3 \%$ & $4.4 \%$ & $1.0 \%$ \\
event & $8.8 \%$ & $11.2 \%$ & $9.8 \%$ \\
combination of events & 0 & $19.5 \%$ & 0 \\
major bleeding & & & \\
\hline
\end{tabular}


risk for thromboembolic complications by $92.9 \%$ (Lubenow et al 2005).

A postmarketing drug monitoring program (DMP) involving 1329 patients treated with lepirudin has also shown the safety and efficacy of the drug in routine clinical practice (Greinacher 2004). The overall mortality rate attributed to a new thrombosis was only $1.4 \%$. These favorable findings are most probably due to increasing knowledge and experience of clinicians. Furthermore, in contrast to the HAT trials, in which lepirudin was started after the laboratory confirmation of HIT, treatment of HIT in the DMP series was started once HIT was suspected.

\section{Lepirudin in special circumstances}

Due to the lack of adequate antidote, the use of lepirudin in disease states requiring extracorporeal systems has been a concern in critical care medicine and CPB surgery. However, observational studies in the last few years have demonstrated that this issue may be solved if appropriate monitoring strategy is implemented.

\section{Lepirudin in artificial renal support}

There are no large studies available on the safety and efficacy of lepirudin in patients on artificial renal support. However, case reports and observational studies have shown that the drug can be safely used in this patient group (Nowak et al 1997; Bucha et al 1999b; Fischer et al 1999; Saner et al 2001; Gajra et al 2007).

Due to the predominantly renal elimination of lepirudin, careful drug dosing and coagulation monitoring are necessary to avoid an overdose in patients with renal dysfunction. Elimination half-lives of up to 316 hours have been reported in dialysis patients (Nowak et al 1992). Vanholder et al (1997) reported hirudin half-life in dialysis patients of more than 30 times than that in healthy controls. Minor improvements in renal function can result in a shorter elimination half-life of lepirudin. Therefore, frequent dose adjustments may be necessary in patients with acute renal failure, whose renal function may improve during the course of treatment (Fischer et al 1999).

The type of dialysis membrane may also affect the pharmacokinetics of lepirudin. While most of the low-flux dialysis membranes are not permeable to hirudin, high-flux membranes may contribute to the elimination of the drug (Bucha et al 1999a; Koster et al 2000c).

Repeated exposures to lepirudin may lead to an increased incidence of hirudin antibodies, which may result in marked reduction in renal clearance of the drug (see below).

\section{Lepirudin in cardiovascular surgery}

Anticoagulation in patients with HIT undergoing CPB surgery poses a special problem. There is a marked activation of the coagulation system due to exposure of circulating blood to artificial surfaces in the CPB pump, making high-dose anticoagulation mandatory. UFH remained in this situation the anticoagulant of choice, because monitoring is easy and rapid and an effective antidote is available.

The issue of adequate monitoring and the lack of an antidote are very important while using lepirudin during CPB. Target lepirudin concentrations during CPB are 3.5 to $4.0 \mu \mathrm{g} / \mathrm{mL}$ (Pötzsch et al 1997b). Due to theses high doses of lepirudin, aPTT is not sufficient for monitoring (Pötzsch et al 1997b; Hafner et al 2002). On the other hand, the lack of an effective antidote implies that an optimal anticoagulant monitoring is crucial to minimize the risk of bleeding. The introduction of ECT has allowed monitoring of lepirudin in high-dose ranges (Pötzsch et al 1997a, b). During CPB surgery, lepirudin dose can be adjusted based on ECT results that can be rapidly obtained using whole blood supplemented with normal human plasma (Pötzsch et al 1997b). This supplementation is important because CPB-associated hemodilution results in hypoprothrombinemia. Reliable ECT data cannot be obtained if plasma prothrombin levels are below $70 \%$ of normal (Koster et al 2000b; Lindhoff-Last et al 2000a).

Observational studies on patients with HIT have shown that cardiovascular surgery can be safely performed with lepirudin if stringent coagulation monitoring is instituted (Pötzsch et al 1997b; Johnston et al 1999; Koster et al 2000a; Fabrizio 2001; Liu et al 2002). In one prospective controlled study comparing lepirudin with heparin in routine CPB surgery, lepirudin was shown to provide effective anticoagulation, but induced a higher postoperative blood loss than heparin (Riess et al 2007).

\section{Lepirudin in pregnancy}

The use of lepirudin in pregnancy is generally not recommended, because the drug crosses the placenta. In a rabbit model, fetal hirudin plasma concentration was 1/60 that of maternal concentration (Markwardt et al 1988). Reports on the use of lepirudin in pregnancy are rare (Huhle et al 2000; Lindhoff-Last and Bauersachs 2002). In general, danaparoid is favored, because it does not cross the placenta (LindhoffLast and Bauersachs 2002; Greinacher 2004).

\section{Lepirudin in children}

The incidence of HIT in the pediatric population is low (Klenner et al 2003; Newall et al 2003; Boning et al 2005), hence 
experience with lepirudin in children is anecdotal (Deitcher et al 2002; Severin et al 2002; Nguyen et al 2003; Knoderer et al 2006). Lepirudin at an infusion rate of $0.1 \mathrm{mg} / \mathrm{kg}$ bodyweight/ hour seems adequate if renal function is normal (Severin et al 2002; Klenner and Greinacher 2004). Further dose adjustments should be made based on coagulation results.

\section{Lepirudin versus other drugs approved for treatment of HIT}

Direct comparative investigations between the drugs used in the treatment of HIT are not existent. Therefore, statements on this issue must be interpreted with caution. Retrospective comparison on the efficacy of lepirudin and argatroban has shown better results with lepirudin than with argatroban (Greinacher 2004). However, due to differences in study design, it is difficult to make a conclusive statement (Warkentin 2003). In another retrospective study by Smythe et al (2005), effective anticoagulation was achieved in $77.8 \%$ of argatroban patients and $69.5 \%$ of lepirudin patients. Major bleeding was documented in $10.3 \%$ and $11.5 \%$ of patients with argatroban and lepirudin, respectively.

In a retrospective study comparing lepirudin with danaparoid, there was no significant difference in efficacy between the two drugs in HIT patients with thrombosis at baseline treated with therapeutic doses (Farner et al 2001).

\section{Complications of lepirudin treatment Bleeding}

Bleeding is the most important and clinically relevant complication of treatment with lepirudin, with an incidence rate of 4\%-19\% (Lubenow et al 2005). The reasons for this wide range in the reported bleeding frequencies may be differences in the study population and in monitoring of treatment. In a post-marketing DMP, the incidence of major bleeding episodes in patients with HIT and thrombosis treated with lepirudin was $5.4 \%$, which is significantly lower than that in the HAT trials (Greinacher 2004). This may be attributed to a greater awareness and experience of physicians in dosing and monitoring lepirudin.

Elderly patients, patients with renal dysfunction and those with multiple organ dysfunction syndrome may be at high risk of bleeding complication. The hemostatic system is disturbed in critically ill patients. Besides renal dysfunction, deterioration in liver function may result in deficiency in coagulation factors, which can contribute to an increasing bleeding risk during treatment with lepirudin.

A further cause of increased bleeding risk during lepirudin administration is the concomitant use of anti-platelet drugs such as acetylsalicylic acid or GPIIb/IIIa inhibitors or fibrinolytic drugs.

Another issue is that the dosing generally recommended for treatment might be too high for a number of patients, who are mainly critically ill patients with at least one organ dysfunction (Lubenow et al 2005).

\section{Antibody development}

Antibody development against hirudins is common, and this can be induced by both iv therapeutic and sc prophylactic doses (Greinacher et al 2003a). In one study, the incidence of antibodies against r-hirudin was $84 \%$ in iv treated patients and 50\% in sc treated patients (Huhle et al 1999). In another study on 196 patients with HIT treated with lepirudin (Eichler et al 2000), 44\% developed antihirudin antibodies of the IgG class, and development of these antibodies correlated with the duration of treatment. Antihirudin antibodies are frequent in patients treated with lepirudin for more than 5 days.

By binding to lepirudin, antihirudin antibodies alter the pharmacokinetics of the drug, resulting in its longer halflife. Because the drug is mainly eliminated via the kidney, formation of lepirudin-antibody complexes may, due to their size, impair renal elimination, which may lead to accumulation of the drug. This phenomenon may thus enhance the anticoagulant effect of lepirudin (Eichler et al 2000). The volume of distribution of these complexes is also decreased, indicating that antibody-bound lepirudin is mainly distributed in the intravascular compartment (Liebe et al 2002). Elimination of the drug using dialysis membranes is also hampered (Fischer et al 2003). Therefore, close coagulation monitoring is important during lepirudin treatment in patients with antihirudin antibodies.

\section{Allergic reaction}

Eczema, rash, hot flushes, fever, chills, urticaria, bronchospasm, angioedema, and injection-site reactions have been reported in conjunction with the administration of lepirudin. Severe anaphylactic reactions have ensued in rare cases in close temporal relationship with the administration of lepirudin. These reactions were observed within minutes of iv bolus lepirudin administration. The risk of anaphylaxis was estimated at $0.015 \%$ for first exposure and $0.16 \%$ for repeat exposure to lepirudin (Greinacher et al 2003b). High titer antihirudin antibodies of the IgG class but not of the IgE class were found in lepirudin-associated anaphylaxis. Avoiding iv bolus administration, if possible, may reduce the risk of severe anaphylactic reactions. 


\section{Conclusion}

Lepirudin has been proved to be effective and safe in the management of HIT. The drug is predominantly eliminated through the kidney. Therefore, renal function is a major determinant during dose adjustments. Important adverse effects are bleeding and development of antihirudin antibodies. The risk of bleeding can be reduced with increasing knowledge of physicians in dose adjustments and by implementing appropriate laboratory monitoring. The development of antihirudin antibodies may necessitate dose adjustments, particularly if patients are to be treated with lepirudin for more than 5 days. Anaphylactic reactions are very rare, and these seem to be associated with iv bolus administration of the drug.

Monitoring of lepirudin treatment can be achieved by means of aPTT in most circumstances. However, the correlation between aPTT and lepirudin is low at higher plasma lepirudin concentrations, such as required in CPB surgery. In such circumstances, ECT seems to be a better means of drug monitoring than aPTT.

The lack of an antidote against lepirudin is still a concern in certain clinical situations, particularly during CPB surgery. Nevertheless, increasing knowledge of physicians on the pharmacology of the drug and proper drug monitoring can help to reduce the risk of bleeding.

\section{Disclosures}

The author has no conflicts of interest to disclose.

\section{References}

Bayer Inc. 2007. Product Monograph Refludan ${ }^{\circledR}$. Toronto.

Becker RC. 2000. Hirudin-based anticoagulant strategies for patients with suspected heparin-induced thrombocytopenia undergoing percutaneous coronary interventions and bypass grafting. J Thromb Thrombolysis, 10(Suppl 1):59-68.

Boning A, Morschheuser T, Blase U, et al. 2005. Incidence of heparininduced thrombocytopenia and therapeutic strategies in pediatric cardiac surgery. Ann Thorac Surg, 79:62-5.

Bove CM, Casey B, Marder VJ. 1996. DDAVP reduces bleeding during continued hirudin administration in the rabbit. Thromb Haemost, 75:471-5.

Bucha E, Kreml R, Nowak G. 1999a. In vitro study of r-hirudin permeability through membranes of different haemodialysers. Nephrol Dial Transplant, 14:2922-6.

Bucha E, Nowak G, Czerwinski R, et al. 1999b. R-hirudin as anticoagulant in regular hemodialysis therapy:finding of therapeutic R-hirudin blood/plasma concentrations and respective dosages. Clin Appl Thromb Hemost, 5:164-70.

Butler KD, Dolan SL, Talbot MD, et al. 1993. Factor VIII and DDAVP reverse the effect of recombinant desulphatohirudin (CGP 39393) on bleeding in the rat. Blood Coagul Fibrinolysis, 4:459-64.

Creekmore FM, Oderda GM, Pendleton RC, et al. 2006. Incidence and economic implications of heparin-induced thrombocytopenia in medical patients receiving prophylaxis for venous thromboembolism. Pharmacotherapy, 26:1438-45.

Crowther MA, Cook DJ, Meade MO, et al. 2005. Thrombocytopenia in medical-surgical critically ill patients:prevalence, incidence, and risk factors. J Crit Care, 20:348-53.
Deitcher SR, Topoulos AP, Bartholomew JR, et al. 2002. Lepirudin anticoagulation for heparin-induced thrombocytopenia. $J$ Pediatr, 140:264-6.

Dodt J, Müller HP, Seemüller U, et al. 1984. The complete amino acid sequence of hirudin, a thrombin specific inhibitor. FEBS, 165:180-4.

Eichler P, Friesen HJ, Lubenow N, et al. 2000. Antihirudin antibodies in patients with heparin-induced thrombocytopenia treated with lepirudin: incidence, effects on aPTT, and clinical relevance Blood, 96:2373-8.

Engelmann F, Stade C. 1909. Über die Bedeutung des Blutegelextraktes für die Therapie der Eklampsie. Münch Med Wochenschr, 43:2203-7.

Fabrizio MC 2001. Use of ecarin clotting time (ECT) with lepirudin therapy in heparin-induced thrombocytopenia and cardiopulmonary bypass. J Extra Corpor Technol, 33:117-25.

Farner B, Eichler P, Kroll H, et al. 2001. A comparison of danaparoid and lepirudin in heparin-induced thrombocytopenia. Thromb Haemost, 85:950-7.

Fischer KG, Liebe V, Hudek R, et al. 2003. Anti-hirudin antibodies alter pharmacokinetics and pharmacodynamics of recombinant hirudin. Thromb Haemost, 89:973-82.

Fischer KG, van de Loo A, Bohler J. 1999. Recombinant hirudin (lepirudin) as anticoagulant in intensive care patients treated with continuous hemodialysis. Kidney Int, 56:S46-50.

Gajra A, Vajpayee N, Smith A, et al. 2007. Lepirudin for anticoagulation in patients with heparin-induced thrombocytopenia treated with continuous renal replacement therapy. Am J Hematol, 82:391-3.

Girolami B, Girolami A. 2006. Heparin-induced thrombocytopenia:a review. Semin Thromb Hemost, 32:803-9.

Girolami B, Prandoni P, Stefani PM, et al. 2003. The incidence of heparininduced thrombocytopenia in hospitalized medical patients treated with subcutaneous unfractionated heparin: a prospective cohort study. Blood, 101:2955-9.

Greinacher A. 2004. Lepirudin for the treatment of heparin-induced thrombocytopenia. In Warkentin TE, Greinacher A (eds). Heparin-induced thrombocytopenia. 3rd ed. New York, Basel:Marcel Dekker. p 397-436.

Greinacher A. 2006. Heparin-induced thrombocytopenia: frequency and pathogenesis. Pathophysiol Haemost Thromb, 35:37-45.

Greinacher A, Eichler P, Albrecht D, et al. 2003a. Antihirudin antibodies following low-dose subcutaneous treatment with desirudin for thrombosis prophylaxis after hip-replacement surgery:incidence and clinical relevance. Blood, 101:2617-9.

Greinacher A, Janssens U, Berg G, et al. 1999a. Lepirudin (recombinant hirudin) for parenteral anticoagulation in patients with heparin-induced thrombocytopenia. Heparin-Associated Thrombocytopenia Study (HAT) investigators. Circulation, 100:587-93.

Greinacher A, Juhl D, Strobel U, et al. 2007. Heparin-induced thrombocytopenia: a prospective study on the incidence, platelet-activating capacity and clinical significance of antiplatelet factor $4 /$ heparin antibodies of the IgG, IgM, and IgA classes. J Thromb Haemost, 5:1666-73.

Greinacher A, Lubenow N, Eichler P. 2003b. Anaphylactic and anaphylactoid reactions associated with lepirudin in patients with heparin-induced thrombocytopenia. Circulation, 108:2062-5.

Greinacher A, Volpel H, Janssens U, et al. 1999b. Recombinant hirudin (lepirudin) provides safe and effective anticoagulation in patients with heparin-induced thrombocytopenia:a prospective study. Circulation, 99:73-80.

Hafner G, Roser M, Nauck M. 2002. Methods for the monitoring of direct thrombin inhibitors. Semin Thromb Hemost, 28:425-30.

Haycraft JB. 1884. On the action of a secretion obtained from the medicinal leech on the coagulation of the blood. Proc R Soc Lond, 36:478-87.

Hein OV, von Heymann C, Morgera S, et al. 2005. Protracted bleeding after hirudin anticoagulation for cardiac surgery in a patient with HIT II and chronic renal failure. Artif Organs, 29:507-10.

Hemker HC, Al Dieri R, De Smedt E, et al. 2006. Thrombin generation, a function test of the haemostatic-thrombotic system. Thromb Haemost, 96:553-61.

Hoffman M, Monroe DM 3rd. 2001. A cell-based model of hemostasis. Thromb Haemost, 85:958-65. 
Huhle G, Geberth M, Hoffmann U, et al. 2000. Management of heparinassociated thrombocytopenia in pregnancy with subcutaneous r-hirudin. Gynecol Obstet Invest, 49:67-9.

Huhle G, Hoffmann U, Song X, et al. 1999. Immunologic response to recombinant hirudin in HIT type II patients during long-term treatment. Br J Haematol, 106:195-201.

Hutchison CA, Dasgupta I. 2007. National survey of heparin-induced thrombocytopenia in the haemodialysis population of the UK population. Nephrol Dial Transplant, 22:1680-4.

Ibbotson SH, Grant PJ, Kerry R, et al. 1991. The influence of infusions of 1-desamino-8-D-arginine vasopressin (DDAVP) in vivo on the anticoagulant effect of recombinant hirudin (CGP39393) in vitro. Thromb Haemost, 65:64-6.

Johnston N, Jessen ME, DiMaio M, et al. 1999. The emergency use of recombinant hirudin in cardiopulmonary bypass. $J$ Extra Corpor Technol, 31:211-5.

Juhl D, Eichler P, Lubenow N, et al. 2006. Incidence and clinical significance of anti-PF4/heparin antibodies of the IgG, IgM, and IgA class in 755 consecutive patient samples referred for diagnostic testing for heparininduced thrombocytopenia. Eur J Haematol, 76:420-6.

Klenner AF, Fusch C, Rakow A, et al. 2003. Benefit and risk of heparin for maintaining peripheral venous catheters in neonates: a placebocontrolled trial. J Pediatr, 143:741-5.

Klenner AF, Greinacher A. 2004. Heparin-induced thrombocytopenia in children. In Warkentin TE, Greinacher A (eds). Heparin-induced thrombocytopenia. 3rd ed. New York, Basel: Marcel Dekker. p 553-71.

Knoderer CA, Knoderer HM, Turrentine MW, et al. 2006. Lepirudin anticoagulation for heparin-induced thrombocytopenia after cardiac surgery in a pediatric patient. Pharmacotherapy, 26:709-12.

Koster A, Hansen R, Kuppe H, et al. 2000a. Recombinant hirudin as an alternative for anticoagulation during cardiopulmonary bypass in patients with heparin-induced thrombocytopenia type II: a 1-year experience in 57 patients. $J$ Cardiothorac Vasc Anesth, 14:243-8.

Koster A, Loebe M, Hansen R, et al. 2000b. A quick assay for monitoring recombinant hirudin during cardiopulmonary bypass in patients with heparin-induced thrombocytopenia type II: adaptation of the ecarin clotting time to the act II device. J Thorac Cardiovasc Surg, 119:1278-83.

Koster A, Merkle F, Hansen R, et al. 2000c. Elimination of recombinant hirudin by modified ultrafiltration during simulated cardiopulmonary bypass:assessment of different filter systems. Anesth Analg, 91:265-9.

Liebe V, Bruckmann M, Fischer KG, et al. 2002. Biological relevance of anti-recombinant hirudin antibodies - results from in vitro and in vivo studies. Semin Thromb Hemost, 28:483-90.

Lindhoff-Last E, Bauersachs R 2002. Heparin-induced thrombocytopeniaalternative anticoagulation in pregnancy and lactation. Semin Thromb Hemost, 28:439-46.

Lindhoff-Last E, Piechottka GP, Rabe F, et al. 2000a. Hirudin determination in plasma can be strongly influenced by the prothrombin level. Thromb Res, 100:55-60.

Lindhoff-Last E, Willeke A, Thalhammer C, et al. 2000b. Hirudin treatment in a breastfeeding woman. Lancet, 355:467-8.

Liu H, Fleming NW, Moore PG. 2002. Anticoagulation for patients with heparin-induced thrombocytopenia using recombinant hirudin during cardiopulmonary bypass. J Clin Anesth, 14:452-5.

Lubenow N, Eichler P, Lietz T, et al. 2005. Lepirudin in patients with heparin-induced thrombocytopenia - results of the third prospective study (HAT-3) and a combined analysis of HAT-1, HAT-2, and HAT-3. $J$ Thromb Haemost, 3:2428-36.

Markwardt F, Fink G, Kaiser B, et al. 1988. Pharmacological survey of recombinant hirudin. Pharmazie, 43:202-7.

Markwardt F, Nowak G, Sturzebecher J. 1991. Clinical pharmacology of recombinant hirudin. Haemostasis, 21(Suppl 1):133-6.

Markwardt F, Nowak G, Sturzebecher J, et al. 1984. Pharmacokinetics and anticoagulant effect of hirudin in man. Thromb Haemost, 52:160-3.
Martel N, Lee J, Wells PS. 2005. Risk for heparin-induced thrombocytopenia with unfractionated and low-molecular-weight heparin thromboprophylaxis: a meta-analysis. Blood, 106:2710-5.

Meyer BH, Luus HG, Muller FO, et al. 1990. The pharmacology of recombinant hirudin, a new anticoagulant. S Afr Med J, 78:268-70.

Moser M, Rue, J, Peter K, et al. 2001. Ecarin clotting time but not aPTT correlates with PEG-hirudin plasma activity. J Thromb Thrombolysis, $12: 165-9$.

Newall F, Barnes C, Ignjatovic V, et al. 2003. Heparin-induced thrombocytopenia in children. J Paediatr Child Health, 39:289-92.

Nguyen TN, Gal P, Ransom JL, et al. 2003. Lepirudin use in a neonate with heparin-induced thrombocytopenia. Ann Pharmacother, 37:229-33.

Nowak G. 2001. Clinical monitoring of hirudin and direct thrombin inhibitors. Semin Thromb Hemost, 27:537-41.

Nowak G, Bucha E. 1996. Quantitative determination of hirudin in blood and body fluids. Semin Thromb Hemost, 22:197-202.

Nowak G, Bucha E, Brauns I, et al. 1997. Anticoagulation with r-hirudin in regular haemodialysis with heparin-induced thrombocytopenia (HIT II). The first long-term application of r-hirudin in a haemodialysis patient. Wien Klin Wochenschr, 109:354-8.

Nowak G, Bucha E, Goock T, et al. 1992. Pharmacology of r-hirudin in renal impairment. Thromb Res, 66:707-15.

Nowak G, Markwardt F, Fink E. 1988. Pharmacokinetic studies with recombinant hirudin in dogs. Folia Haematol Int Mag Klin Morphol Blutforsch, 115:70-4.

Oh JJ, Akers WS, Lewis D, et al. 2006. Recombinant factor VIIa for refractory bleeding after cardiac surgery secondary to anticoagulation with the direct thrombin inhibitor lepirudin. Pharmacotherapy, 26:569-77.

Petros S, Siegemund T, Siegemund A, et al. 2006. The effect of different anticoagulants on thrombin generation. Blood Coagul Fibrinolysis, 17:131-7.

Pötzsch B, Hund S, Madlener K, et al. 1997a. Monitoring of recombinant hirudin:assessment of a plasma-based ecarin clotting time assay. Thromb Res, 86:373-83.

Pötzsch B, Madlener K, Seelig C, et al. 1997b. Monitoring of r-hirudin anticoagulation during cardiopulmonary bypass - assessment of the whole blood ecarin clotting time. Thromb Haemost, 77:920-5.

Prandoni P, Siragusa S, Girolami B, et al. 2005. The incidence of heparininduced thrombocytopenia in medical patients treated with low-molecularweight heparin:a prospective cohort study. Blood, 106:3049-54.

Riess FC, Poetzsch B, Madlener K, et al. 2007. Recombinant hirudin for cardiopulmonary bypass anticoagulation: a randomized, prospective, and heparin-controlled pilot study. Thorac Cardiovasc Surg, 55:233-8.

Roberts HR, Hoffman M, Monroe DM. 2006. A cell-based model of thrombin generation. Semin Thromb Hemost, 32 (Suppl 1):32-8.

Saner F, Hertl M, Broelsch CE. 2001. Anticoagulation with hirudin for continuous veno-venous hemodialysis in liver transplantation. Acta Anaesthesiol Scand, 45:914-8.

Schiele F, Vuillemenot A, Kramarz P, et al. 1994. A pilot study of subcutaneous recombinant hirudin (HBW 023) in the treatment of deep vein thrombosis. Thromb Haemost, 71:558-62.

Selleng K, Warkentin TE, Greinacher A. 2007. Heparin-induced thrombocytopenia in intensive care patients. Crit Care Med, 35:1165-76.

Severin T, Zieger B, Sutor AH. 2002. Anticoagulation with recombinant hirudin and danaparoid sodium in pediatric patients. Semin Thromb Hemost, 28:447-54.

Smythe MA, Koerber JM, Mattson JC. 2007. The incidence of recognized heparin-induced thrombocytopenia in a large, tertiary care teaching hospital. Chest, 131:1644-9.

Smythe MA, Stephens JL, Koerber JM, et al. 2005. A comparison of lepirudin and argatroban outcomes. Clin Appl Thromb Hemost, 11:371-4.

Strauss R, Wehler M, Mehler K, et al. 2002. Thrombocytopenia in patients in the medical intensive care unit: bleeding prevalence, transfusion requirements, and outcome. Crit Care Med, 30:1765-71.

Vanholder R, Camez A, Veys N, et al. 1997. Pharmacokinetics of recombinant hirudin in hemodialyzed end-stage renal failure patients. Thromb Haemost, 77:650-5. 
Verstraete M, Nurmohamed M, Kienast J, et al. 1993. Biologic effects of recombinant hirudin (CGP 39393) in human volunteers. European Hirudin in Thrombosis Group. $J$ Am Coll Cardiol, 22:1080-8.

Wallis DE, Workman DL, Lewis BE, et al. 1999. Failure of early heparin cessation as treatment for heparin-induced thrombocytopenia. Am J Med, 106:629-35.

Warkentin TE. 2003. Management of heparin-induced thrombocytopenia:a critical comparison of lepirudin and argatroban. Thromb Res, 110:73-82.

Warkentin TE. 2004. An overview of the heparin-induced thrombocytopenia syndrome. Semin Thromb Hemost, 30:273-83.
Warkentin TE, Heddle NM. 2003. Laboratory diagnosis of immune heparininduced thrombocytopenia. Curr Hematol Rep, 2:148-57.

Warkentin TE, Levine MN, Hirsh J, et al. 1995. Heparin-induced thrombocytopenia in patients treated with low-molecular-weight heparin or unfractionated heparin. $N$ Engl J Med, 332:1330-5.

Weitz JI, Hudoba M, Massel D, et al. 1990. Clot-bound thrombin is protected from inhibition by heparin-antithrombin III but is susceptible to inactivation by antithrombin III-independent inhibitors. J Clin Invest, 86:385-91.

Yamamoto S, Koide M, Matsuo M, et al. 1996. Heparin-induced thrombocytopenia in hemodialysis patients. Am J Kidney Dis, 28:82-5. 